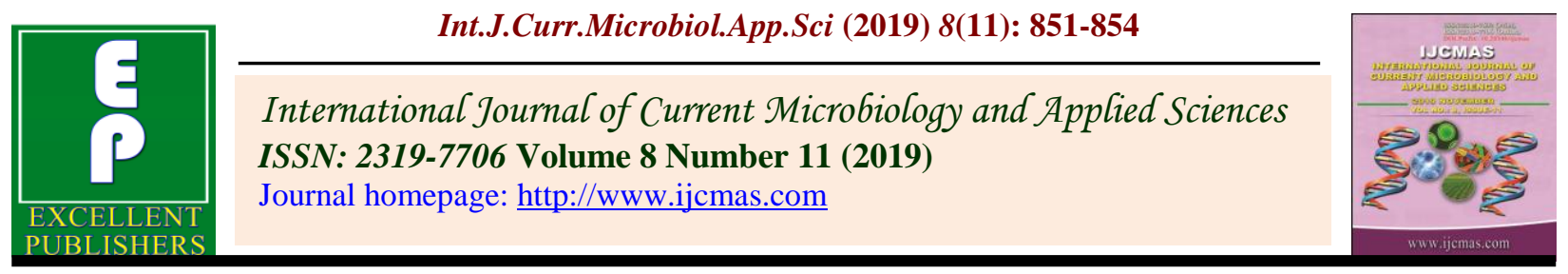

Case Study

https://doi.org/10.20546/ijcmas.2019.811.100

\title{
Dystocia Due to Hydroallantois and Congenital Foetal Ascites in a Murrah Buffalo - A Case Report
}

\author{
Amit Kumar $^{1 *}$, Gyan Singh², V. Arjun ${ }^{1}$, Hariom$^{1}$, V.K. Jain ${ }^{2}$ and R.K. Chandolia ${ }^{1}$ \\ ${ }^{1}$ Department of Veterinary Gynaecology and Obstetrics, ${ }^{2}$ Department of Veterinary Clinical \\ Complex, College of Veterinary Sciences, Lala Lajpat Rai University of Veterinary and \\ Animal Sciences, Hisar-125004 (Haryana) India
}

*Corresponding author

Keywords

Cloprostenol,

Estradiol valerate,

Fetal ascites

Article Info

Accepted:

07 October 2019

Available Online:

10 November 2019

\section{A B S T R A C T}

\section{Introduction}

Hydroallantois is one of the gestational disorder in which sudden increase in allantoic fluid occurs in allantoic cavity due to foetal membrane pathology leading to bilateral enlargement of abdomen (Roberts, 1971). This is more common in last phase of third trimester in dairy and beef cattle and less so in buffaloes and heifers (Srinivas and Sreenu, 2006). Hydrallantois is usually considered as maternal abnormality, where the rapid and abnormal distension of abdomen occurs (Drivers and Peek, 2008) due to rapid accumulation of watery, amber color fluid inside the allantoic cavity over a period of 5 to 20 days in late gestation and is always giving suspicion for twin/triplet pregnancy (Morrow, 1986). It accounts for about $80-90 \%$ of uterine hydrops (Sloss and Dufty, 1980; Selvaraju et al., 2012).

This condition invariably results in fetal gestational accident owing to placental dysfunction and fetal kidney failure (Arthur et al., 1989; Jana and Ghosh, 2012). Roberts (1971) stated that this dropsical condition usually affects both fetus and fetal membranes. It is usually seen sporadically in dairy and beef cattle. It is usually associated with a diseased uterus in which most of the caruncles in one horn are not functional and rests of the placentomes are greatly enlarged and possibly diseased (Roberts, 1971). 


\section{Case history and clinical observations}

A seven year old pregnant Murrah buffalo at full term was presented to Veterinary Clinical Complex with the history of sudden enlargement of abdomen (Fig. 3), respiratory discomfort and progressive anxiety. The buffalo was dull and depressed with sunken eye balls, dry muzzle and severely dehydrated body. Per-rectal examination revealed grossly distended uterus and inability to palpate the fetus. On per vaginal examination, the cervix was found to be closed. Based on history, symptoms and observations, the case was diagnosed as hydroallantois.

\section{Treatment and Discussion}

The animal was treated with $2 \mathrm{ml}$ Metrum (Cloprostenol; Macwell Pharma) IM, $10 \mathrm{ml}$ Dexona (Dexamethsone; Zydus AHL) IM, 10 $\mathrm{ml}$ Epidosin (Valethamate bromide; TTK) IM, $10 \mathrm{ml}$ Avil (Chlorpheniramine maleate; MSD Animal Health) IM, 2ml Pregheat ${ }^{\circledR}$ (Estradiol valerate; Virbac India)IM, $450 \mathrm{ml}$ of Mifex ${ }^{\circledR}$ (Calcium-magnesium-boro-gluconate; Novartis India Limited) IV and 5 litres of Dextrose Normal Saline (Dextrose 5\%; Fresenius Kabi) IV.

After 12 hours, per vaginal examination revealed complete dilatation of cervix and presence of water bag in birth canal. So $10 \mathrm{ml}$ Pitocin (Oxytocin; Pfizer) in 1 liter of Dextrose Normal Saline (Dextrose 5\%; Fresenius Kabi) IV, 4 litres of Dextrose Normal Saline (Dextrose 5\%; Fresenius Kabi) was given subsequently. After 30 minutes of administration of oxytocin, large quantity of watery and amber coloured allantoic fluid oozed out. Assisted delivery yielded ascitic fetus (Fig. 2) followed by expulsion of oedematous placenta having abnormal cotyledons (Fig. 1). Post mortem of dead foetus revealed presence of ascitic fluid in abdominal cavity. The uneventful recovery of the dam was noticed. Similar recovery has been reported by Bhoi (2010) in a nondescript buffalo.

Dropsical conditions of the concepts appear to be one of the most important factors leading to dystocia (Noakes et al., 2001). Both the amniotic and allantoic sacs can accumulate excessive quantities of fetal fluid, thus referred as Hydramnios or hydrallantois, depending on involvement of sac. Hydrallantois and Hydramnios represent dropsy of fetal sacs. According to Vandeplassche et al., (1965) hydrallantois is most common (88\%), hydramnion occurs rarely $(5 \%)$ and about (7\%) cases occur together. Hydroallantois is commonly associated with either infectious diseases or developmental defects of foetus. Fetal dropsical conditions such as ascites have been previously reported in buffalo with hydroallantois (Srinivas and Sreenu, 2006). Accumulation of allantoic fluid is rapid due to placental abnormalities and possible interference with sodium metabolism at cellular level (Jackson, 1980).

Pregnancy in buffaloes affected with hydroallantois was terminated successfully using dexamethasone (Chandolia et al., 1988 and Prabhakar et al., 1991), prostaglandin analogues (Chandolia et al., 1989) and combination of prostaglandin and corticosteroid (Luthra et al., 2001).

Similar to the present case report of hydroallantois was seen mostly during last month of gestation and its treatment always recommends administration of fluid intravenously and termination of pregnancy. If a large volume of allantoic fluid in the uterus is expelled rapidly, circulatory shock may develop. In the present case, the combined therapy of Lutalyse, Dexona, Epidosin and rapid infusion of DNS to avoid hypovolumic shock, helped in recovery of the dam. 


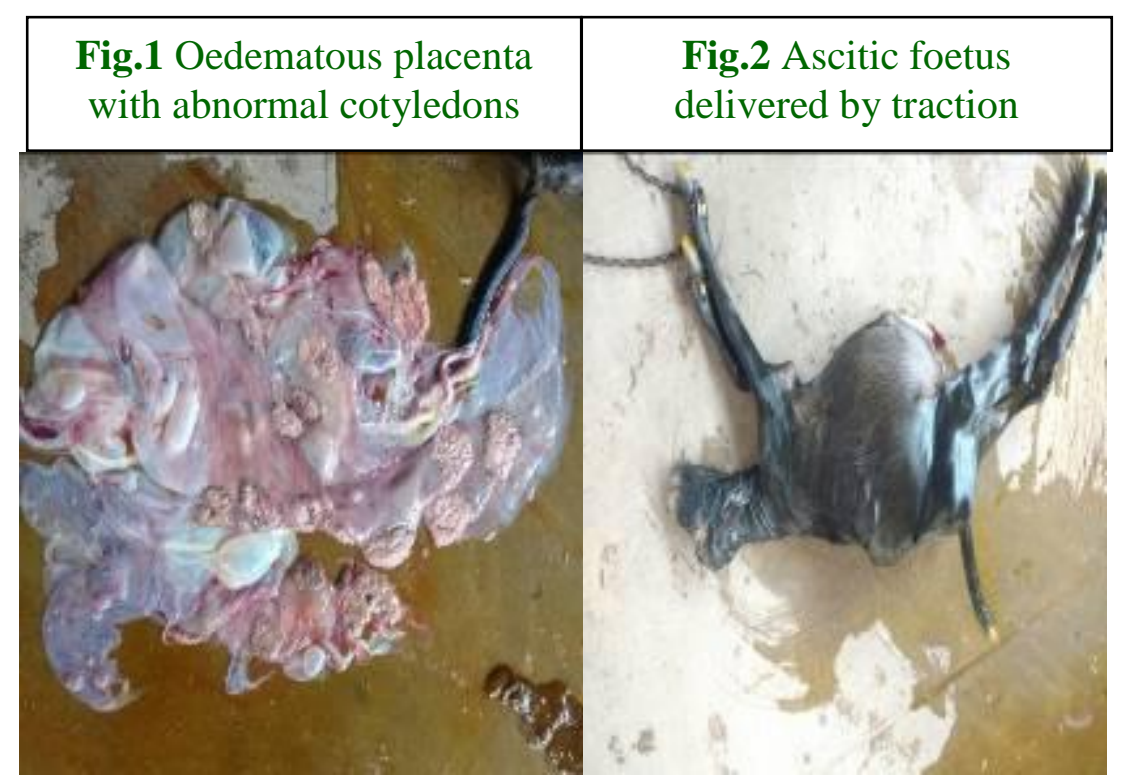

Fig.3 Abdominal distension in affected buffalo

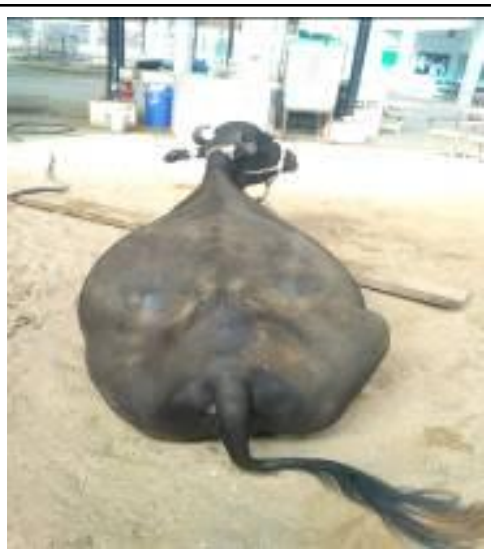

\section{References}

Arthur, G.H., Noakes, D.E. and Pearson, H. (1989). Veterinary Reproduction and Obstetrics, ELBS, 118-120.

Bhoi, D.B. (2010). International Symposium on "Biotechnologies for optimization of reproductive efficiency of dam and companion animals to improve global food security and human health" and XXVI Annual Convention of ISSAR, Nov. 10-12, held at G.B.P.U.A \& T. Pantnagar. p 156 (abstract).

Chandolia, R.K., Khar, S.K. Chander, S. and
Verma, S.K. (1988). Induction of parturition with dexamethasone in buffalo with hydroallantois. Indian. Vet. J. 65: 156-158.

Chandolia, R.K., Verma, S.K., Chander, S., Singh, N. and Chandana, I.S. (1989). Response of two buffaloes with hydroamnios and hydroallantois to treatment with dinoprost - a case report. Indian Vet. J. 66: 861-864.

Drivers TJ, Peek S. (2008). Rebhun's diseases of dairy cattle. $2^{\text {nd }}$ edn. Saunders Elsevier, St. Louis, Missouri. Pp. 395.

Jackson, P.G.G. (1995). Handbook of 
Veterinary Obstetrics, $2^{\text {nd }}$ edn. W.B. Saunders Company Philadelphia, USA. Pp. 123-127.

Jana, B and Ghosh, M. (2012). Indian Journal of Field Veterinarians.7(4): 51-52.

Luthra, R.A., Khar, S.K. and Nanda, T. (2001). Therapeutic management of hydroallantois in buffaloes. Intas Polivet. 2: 24-26.

Misri, J. and Singh, N. (2001). Hydrallantois in a goat. Indian Vet. J. 78(3): 255256.

Morrow AD. (1986). Current Therapy in Theriogenology. WB Saunders Company, Philadelphia, USA. 207208.

Noakes, D.E., Parkinson, T.J. and England, G.C.W. (2009). Veterinary Reproduction and Obstetrics, $9^{\text {th }}$ Edn. Saunders Elsevier. p 141.

Noakes, D.E., Parkinson, D.J. and England, G.C.W. (2001). Anomalies of development of the conceptus Teratology In Noakes, D.E., $\left(8^{\text {th }}\right.$ edn.) Arthurs Veterinary Reproduction and Obstetrics, Saunders Harcourt, India,
119-120.

Prabhakar, S., Dhaliwal, G.S. and Sharma. R.D. (1991). Effect of dexamethasone in the treatment of hydroallantois in buffaloes. Indian. Vet. J. 68: 10901091.

Roberts, S.J. (1971). Veterinary Obstetrics and Genital diseases. $2^{\text {nd }}$ Edn. CBS Publishers and Distributors. p 180.

Selvaraju, M., Manokaran, S., Palanisamy, M., Napolean, R.E. and Ravikumar, K. (2012). Hydroallantois in a she buffalo. Indian J. Anim. Reprod. 33(1): 92-93.

Sloss, V. and Duffy, J. H. (1980). Handbook of bovine obstetrics. Williams and Wilkins, Baltimore, USA.

Srinivas, M. and Sreenu, M. (2006). Hydrallantois with fetal ascites in a Buffalo. Indian Vet. J. 83: 1342-1343.

Vandeplassche, M., Oyaert, W., Bouters, R., Vandenhende, C., Spincemaille, J. and Hermann, J. (1965). Über die Eihautwassersucht beim Rind. Wiener Tiearztliche Monatsschrift. 52: 461.

\section{How to cite this article:}

Amit Kumar, Gyan Singh, V. Arjun, Hariom, V.K. Jain and Chandolia, R.K. 2019. Dystocia Due to Hydroallantois and Congenital Foetal Ascites in a Murrah Buffalo - A Case Report. Int.J.Curr.Microbiol.App.Sci. 8(11): 851-854. doi: https://doi.org/10.20546/ijcmas.2019.811.100 